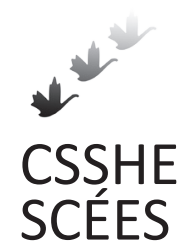

Canadian Journal of Higher Education Revue canadienne d'enseignement supérieur

Volume 43, No. 1, 2013, pages 129-145

\title{
Gender and Specialty in Business Management Education
}

\author{
Gerald Hunt \& Fei Song
}

Ryerson University

\begin{abstract}
Undergraduate university enrolment in Canada is characterized by a higher proportion of women to men, with a pattern of gender segregation across some disciplines. Within some disciplines, there is also a pattern of internal sex segregation whereby women and men still sort themselves into gendered sub-fields, a pattern that is particularly evident in undergraduate business management programs. This study set out to understand why this segregation occurs. The study found that men and women use the same criteria in selecting a business major, including beliefs about success and fit, as well as advice from referent others. However, they attach different weight to these factors in a pattern that is gendered.
\end{abstract}

\section{Résumé}

L'effectif universitaire de premier cycle au Canada est caractérisé par un ratio plus élevé de femmes par rapport aux hommes, mais avec un modèle de ségrégation entre les sexes dans certaines disciplines. En effet, à l'intérieur de certaines disciplines existe un modèle de ségrégation fondée sur le sexe, où les femmes et les hommes classent encore leurs professions en souscatégories en fonction de leur sexe. Cela est particulièrement évident dans les programmes de premier cycle en gestion d'entreprise, et la présente étude visait à comprendre pourquoi cela se produit. L'étude a révélé que les hommes et les femmes utilisent les mêmes critères dans le choix d'une majeure en études commerciales, surtout en ce qui a trait aux croyances quant à la réussite et aux aptitudes, ainsi qu'aux conseils obtenus d'autres références. Toutefois, les femmes et les hommes attachent une importance différente à ces facteurs selon leur sexe. 
Until the 1970s, Canadian universities were mainly the preserve of men. In 1920, 71\% of undergraduate students were male and 29\% were female (Statistics Canada, 2009). By 1950, the number of women had dropped to 22\% (Statistics Canada, 2009); however, by 1975, women had gained momentum and represented $42 \%$ of the undergraduate population (Statistics Canada, 2009). During the 1990s, the percentage of men in Canadian universities began to shift again, and by 1998, the undergraduate male population had dropped to $45 \%$, and the female population had risen to 55\% (Canadian Association of University Teachers [CAUT], 2002). A decade later, this trend was well established, with $43 \%$ male and $57 \%$ female undergraduates (CAUT, 2009). Not surprisingly, the shifting gender composition of undergraduate university enrolments has caught the attention of educators, policy-makers, and scholars.

As increasing numbers of women began to enrol in undergraduate university programs, another issue became apparent. Female students were tending to segregate away from sciences and math, and they were much less likely to be found in disciplines emphasizing these subjects (such as engineering and computing), even though their overall participation in university programs was increasing. At the same time, disciplines that had traditionally attracted female students (such as nursing, nutrition, and social work) continued to do so, but without increased uptake by males (Pullen \& Simpson, 2009).

As a result, undergraduate university enrolment in Canada is now characterized by a higher proportion of women to men, with a pattern of gender segregation across a number of disciplines. A closer examination of undergraduate enrolment data revealed another phenomenon. Even in disciplines that appear to be gender-neutral, a pattern of internal sex segregation can emerge whereby women and men segregate into sub-fields of study and, as a result, professional practice. This segregation is particularly evident in undergraduate business management and commerce programs. Although undergraduate student enrolment in business management programs appears to reflect the overall ratio of female to male (54\% female to $47 \%$ male), there is a clear pattern of sex segregation across specializations (CAUT, 2009). Some sub-fields such as human resources management have low participation rates by men (31\%), whereas other specializations such as finance and entrepreneurship have low participation by women (39\% and $42 \%$, respectively) (CAUT, 2009). These differences are less pronounced in sub-fields such as accounting and marketing, where women dominate, but in a pattern more reflective of their overall numbers in business management programs. As a result, these latter specialties can be thought of as gender-neutral.

Although sex segregation by specialty in undergraduate business management programs in Canada is a fact, not much attention has been paid to understanding why the phenomenon occurs, even though it warrants scrutiny. If business students are basing their specialization choices on misinformation and stereotypes, or on perceptions that some areas of business are more suitable to one gender rather than another, then business educators need to know this decision-making process so they can attempt to counteract any false perceptions and assist students with accurate information. Indeed, as Mastekaasa \& Smeby pointed out, "Gender segregation in higher education is a major factor behind the uneven distribution of women and men across occupations, and thus also to gender differences in wages" (2008, p. 190). 
The research reported in this paper was designed to expose and compare the rationale men and women use when making decisions about specialization options in undergraduate business management education. A review of the literature identified five key decision factors that explain education choice (potential career success, social fit, individual fit, advice from others, and prior educational experiences). These five decision factors became the basis for designing a questionnaire administered to a cohort of full-time undergraduate business students. The results of the survey indicated that men and women use the same factors, but with different weight when making a specialization choice.

\section{Explaining Educational Decision Making}

Ajzen and Fishbein's theory of reasoned action is a well-established template for understanding and predicting behaviour (Ajzen \& Fishbein, 1980; Fishbein \& Ajzen, 1975). This theory explains behavioural action as the "reasoned" outcome of attitudes/beliefs and subjective influences. In other words, behavioural decisions result from the attitudes one holds toward an option (positive or negative), in combination with the perception one holds about how significant others will view the behaviour (appropriate or inappropriate). Using this theoretical framework, educational choice results from attitudinal factors (in the form of beliefs about various educational options and outcomes) and social factors or subjective norms (in the form of subjective inferences from important others such as peers and parents).

A considerable literature has developed citing various factors that affect educational choice, with these factors falling into the two broad categories highlighted above (attitudes/beliefs and subjective inferences/norms). The factors are summarized in Table 1.

The attitudinal and subjective factors cited in Table 1 can in turn be summarized within five key decision-making categories. Under attitudinal factors, three key categories emerge: beliefs about career success, beliefs about potential social fit, and beliefs about individual fit. Under subjective norms, two key factors emerge: advice from referent others and perceptions of what other will think, along with subjective interpretations gained from prior educational experience. Table 2 provides a summary of these five key decisionmaking factors grouped by beliefs/attitudes and subjective norms.

\section{What Role Does Gender Play?}

Because a distinct pattern of sex segregation in evident in business management majors, it is reasonable to wonder if decision making within the five key factors just identified would vary by gender. In particular, does what a student believes about his or her likely enjoyment of, material gain from, social value associated with, and personal ability to succeed in a discipline, vary by gender, vary not only in valence, but also in the importance or weight associated with each factor? That is, does discipline choice vary by gender within both attitudinal and subjective norm categories? This question leads to two hypotheses:

Hypothesis 1: The selection of business major will be influenced by gender-based beliefs, evaluation, and attitudes.

Hypothesis 2: The gender-based beliefs, evaluation, and attitudes will mediate the relationship between gender and the selection of business major. 
Table 1

\section{Attitudinal and Social Factors Influencing Educational Choice}

\begin{tabular}{|c|c|c|}
\hline \multicolumn{3}{|l|}{ 1. Beliefs/Attitudes } \\
\hline Belief concerning & Attribute & Reference \\
\hline Enjoyment & $\begin{array}{l}\text { Perceived potential satisfaction with } \\
\text { occupation, educational choice; in- } \\
\text { terest in/relevance of subject matter }\end{array}$ & Bowlby \& McMullen, 2002 \\
\hline Material gain & $\begin{array}{l}\text { Belief about economic and material } \\
\text { gain from choice }\end{array}$ & $\begin{array}{l}\text { Franke, 2004; Harris, Thiele, \& Currie, } \\
1998\end{array}$ \\
\hline Social value & $\begin{array}{l}\text { Belief about how much choice will be } \\
\text { of social value; application to real } \\
\text { world (versus theory) }\end{array}$ & Stone \& McKee, 2000 \\
\hline Ability & $\begin{array}{l}\text { Belief about what abilities/attributes } \\
\text { are necessary; competitiveness of } \\
\text { program }\end{array}$ & Hébert, 2000; Trusty, 2002 \\
\hline Balance & $\begin{array}{l}\text { Belief about how much work-life bal- } \\
\text { ance choice will offer }\end{array}$ & Aveling, 2002; Herzig, 2004 \\
\hline $\begin{array}{l}\text { Overall gender } \\
\text { appropriateness }\end{array}$ & $\begin{array}{l}\text { Early socialization; degree to which } \\
\text { major choice is seen as male or } \\
\text { female appropriate }\end{array}$ & Alloway \& Gilbert, 2004; Marks, 2003 \\
\hline Pedagogy & $\begin{array}{l}\text { Fit with learning style; cooperative } \\
\text { versus competitive learning mode }\end{array}$ & Loo, 2002; Moogan \& Baron, 2003 \\
\hline \multicolumn{3}{|c|}{ 2. Subjective Norms } \\
\hline Reference point & Attribute & Reference \\
\hline Peers & $\begin{array}{l}\text { What peers will think; stereotypes used } \\
\text { by peers; need to fit in/feel popular; } \\
\text { friends selecting major }\end{array}$ & $\begin{array}{l}\text { Gough \& Peace, 2000; Noguera, 2003; } \\
\text { O’Brien, } 2003\end{array}$ \\
\hline Parents & Family background; parental wishes & $\begin{array}{l}\text { Aaker, 2000; David, Ball, Davies, \& } \\
\text { Reay, 2003; Dryler, 1998; Finnie \& } \\
\text { Laport, \& Laschelles, 2003; Le \& Miller, } \\
\text { 2002; Tinklin, } 2003\end{array}$ \\
\hline Role models & Parent, friend, or relative in occupation & $\begin{array}{l}\text { David et al., 2003; Mastekaasa \& } \\
\text { Smeby, 2008; Rask \& Bailey, 2002; Til- } \\
\text { leczek \& Lewko, } 2001\end{array}$ \\
\hline Media & $\begin{array}{l}\text { Positive/negative presentation of } \\
\text { choice/occupation on television, } \\
\text { radio, newspaper, etc.; "celebrity" in } \\
\text { occupation }\end{array}$ & Alloway \& Gilbert, 2004 \\
\hline Teachers & $\begin{array}{l}\text { Attitudes/values of teachers to choice; } \\
\text { role models }\end{array}$ & Hatchell, 1998; Rask \& Bailey, 2002 \\
\hline $\begin{array}{l}\text { Climate of } \\
\text { classroom }\end{array}$ & $\begin{array}{l}\text { Organization and culture of the course } \\
\text { and programs; "chilly" climate; will } \\
\text { this major provide the sort of climate } \\
\text { and level of social friendliness I want }\end{array}$ & $\begin{array}{l}\text { Erwin \& Maurutto, 1998; Ferreira, } \\
\text { 2003; Greenfield, Parle, \& Holder, } \\
\text { 2001; Warrington \& Younger, } 2000\end{array}$ \\
\hline Legislation/legal & $\begin{array}{l}\text { Is there a legal apparatus in this field } \\
\text { that will help or harm me }\end{array}$ & referenced in articles, but not tested \\
\hline
\end{tabular}


Table 2

Five Key Decision Factors Influencing Educational Choice

\begin{tabular}{ll}
\hline Decision Factor & Attribute \\
\hline $\begin{array}{l}\text { A. Beliefs/Attitudes } \\
\text { Beliefs about career success }\end{array}$ & Material success, desirable career \\
Beliefs about potential social fit & Allows work-life balance \\
Beliefs about individual fit & Job/person fit: enjoyability, personality, and skills fit \\
$\begin{array}{ll}\text { B. Subjective Norms } \\
\text { Advice from referent others/percep- }\end{array}$ & $\begin{array}{l}\text { Significant others: peers, family, counsellor, faculty } \\
\text { tions of what others will think }\end{array}$ \\
Academic experience & Eember, etc. \\
\hline
\end{tabular}

\section{Methodology and Sample Characteristics}

To test the hypotheses, a questionnaire was designed to use with business students, based on the five key decision-making factors identified in Table 2. The questionnaire consisted of 36 statements to assess the impact of the five decisional factors to which answers were elicited along a 5-point, disagree-agree scale. In addition, the questionnaire included several questions related to perceptions of how gender would influence the likelihood of career success. This set of questions solicited opinions, again on a 5-point scale, about the likelihood of career success for women and men in each specialization. The questionnaire was designed to be reflective, focusing on the rationale and reasoning students had used to select a major.

The questionnaire was administered to undergraduate management students in a large Canadian university in an urban setting. At this university, students are admitted to a Bachelor of Commerce program without being admitted to any particular specialization. At the end of their first year of studies, students select one of seven majors (Accounting, Economics and Management Science, Entrepreneurship, Finance, Human Resources Management, Marketing, and Management). ${ }^{1}$ Their choice of specialization maps a prescriptive course of study for the balance of their undergraduate education, designed to lead them toward a career in that sub-field.

The survey was administered to 420 Bachelor of Commerce students in the term before their graduation. In this cohort of students, $55 \%$ were female and $45 \%$ were male. The survey was administered in the final-year capstone course that all students, regardless of major, are required to take before they graduate. In this course, students are taught in classes of 45 students. The researchers entered the classes to administer the survey, but they did not teach the course. Nine class sections, drawing on a representative population from all seven majors, completed the anonymous questionnaire. A total of 352 students filled out the survey, representing a return rate of $83 \%$.

The average age of the students in the sample was 23. The gender composition of the sample by major is shown in Table 3. As in other business programs in Canada, students in this sample tended to segregate into majors by gender, and this characteristic has been evident at this school for a number of years. Indeed, as we have already stated, one of the 
motivations for the research was to understand this gendered phenomenon. As Table 3 reveals, Human Resources Management was the only female-dominated field, with seven men (21.9\%) among the 32 respondents in this major. Economics and Management Science, Entrepreneurship, Finance, and Management had between $33 \%$ and 37\% women. Only Accounting and Marketing had close to a gender balance. In four majors, men outnumbered women about 2:1; in one field, women outnumbered men 3:1; and in two fields, men and women were present in roughly equal numbers.

Table 3

Gender Composition of Sample by Major

\begin{tabular}{lcccc}
\hline Major & $\begin{array}{c}\text { Overall } \\
\text { response }\end{array}$ & Male & Female & \% Female \\
\hline Accounting & 67 & 34 & 33 & $49 \%$ \\
Economics and Management Science* & 18 & 12 & 6 & $33 \%$ \\
Entrepreneurship* & 17 & 11 & 6 & $35 \%$ \\
Finance & 93 & 61 & 32 & $35 \%$ \\
Human Resources Management & 32 & 7 & 25 & $78 \%$ \\
General Management & 49 & 30 & 19 & $37 \%$ \\
Marketing & 76 & 36 & 40 & $53 \%$ \\
Total & 352 & 191 & 161 & $46 \%$ \\
\hline
\end{tabular}

\section{Results of the Survey}

Data from the survey were analyzed in a number of ways. First, the relative importance of the five decision-making factors among all respondents and by gender was determined (see Table 4). Tests were then conducted to assess any differences in the levels of importance that men and women might attach to each of the factors (see Table 5). Next, respondents were clustered into three groups of majors (male-dominated, female-dominated, and gender-neutral) for an analysis of variance and a regression analysis to determine the impact of the decision factors on major choice (see Tables 6, 7, and 8). Subsequently, mediation and moderation analyses were undertaken to test the hypothesized mediation framework (see Tables 9 and 10). Finally, the degree to which males and females differed in their perceptions of the role of gender in career success was assessed.

Importance of factors. Table 4 presents the mean responses on each of the five decisional factors in a Likert scale, where 5 represents strong influence. The last column reports $t$ tests and associated two-tailed $p$ values on the test of mean differences between men and women. As can been seen, women and men overall attach similar priorities to each of the factors, with the same ordering of factors. Individual fit is considered most important, with career success closely following, and academic experience closely behind that. Social fit is next, with advice from others least important. It is certainly possible that 
students would under-report the latter because many would want to avoid being strongly linked to parental preferences. We might also imagine that the career success factor is under-reported by students who wish to appear more altruistic than they feel. Nevertheless, the ranking of factors showed an intriguing mix of extrinsic and intrinsic factors, and reflected the perceptions of students about their choices.

Gendered differences in rankings. Although the rankings were consistent between men and women, two-sample $t$ tests revealed that men and women attached differing levels of importance to four of these five factors. Specifically, men considered career success, social fit, and advice from others to be significantly more important, whereas women considered individual fit as significantly more important. Additional correlation analysis, presented in Table 5, also indicated that these factors were correlated with each other. As result of these preliminary findings, subsequent analyses of the data on the impact of these decision factors on self-selection into a major controlled for other factors in order to obtain an independent and unbiased statistical inference.

Table 4

Importance of Decision Factors in Major Choice

\begin{tabular}{lcccc}
\hline Decision Factor & $\begin{array}{c}\text { Total } \\
\text { Mean }^{\mathrm{a}}\end{array}$ & $\begin{array}{c}\text { Mean } \\
\text { (Women) }\end{array}$ & $\begin{array}{c}\text { Mean } \\
\text { (Men) }\end{array}$ & $\begin{array}{c}t \text { test on Gender Difference } \\
\text { (two-tailed } p \text { values) }\end{array}$ \\
\hline Career success & 3.6 & 3.6 & 3.7 & $\begin{array}{c}-1.80 \\
(.071)\end{array}$ \\
Social fit & 3.1 & 3.1 & 3.0 & $\begin{array}{c}0.77 \\
.440)\end{array}$ \\
Individual fit & 4.1 & 4.2 & 4.0 & $\begin{array}{l}1.86 \\
(.062) \\
\text { Advice }\end{array}$ \\
Academic experience & 2.0 & 1.9 & 2.1 & $\begin{array}{c}(.022) \\
0.08 \\
\end{array}$ \\
& 3.4 & 3.4 & 3.4 & $(.934)$ \\
\hline
\end{tabular}

${ }^{\text {a }}$ Scaled 1 to 5 where 5 indicates strong influence.

Table 5

Correlations of Decision Factors (Two-Tailed p Values in Parentheses)

\begin{tabular}{|c|c|c|c|c|}
\hline & 1. & 2. & 3. & 4. \\
\hline 1. Career success & - & & & \\
\hline 2. Social fit & $\begin{array}{l}0.41 \\
(.000)\end{array}$ & - & & \\
\hline 3. Individual fit & $\begin{array}{l}0.17 \\
(.001)\end{array}$ & $\begin{array}{l}0.31 \\
(.000)\end{array}$ & - & \\
\hline 4. Advice & $\begin{array}{l}0.25 \\
(.000)\end{array}$ & $\begin{array}{l}0.25 \\
(.000)\end{array}$ & $\begin{array}{r}-0.02 \\
(.778)\end{array}$ & - \\
\hline 5. Academic experience & $\begin{array}{l}0.29 \\
\text { (.000) }\end{array}$ & $\begin{array}{l}0.31 \\
\text { (.000) }\end{array}$ & $\begin{array}{l}0.40 \\
(.000)\end{array}$ & $\begin{array}{l}0.15 \\
(.005)\end{array}$ \\
\hline
\end{tabular}


Variance across majors. Next, students were clustered according to three groups of majors: male-dominated, female-dominated, and gender-neutral. Table 6 reports the results of an Analysis of Variance Analysis (ANOVA). These results indicated that three of these factors significantly influenced choice; namely, career success, social fit, and individual fit. Table 7 reports the supplementary regression analysis using the five decision factors as independent variables and the three types of business majors as the dependent variable. The dependent variable was coded as a categorical variable. Specifically, maledominated majors were coded as 1 , female-dominated majors were coded as -1 , and gender-neutral majors were coded as 0 . All five decision factors were simultaneously entered into the regression to control for each other in order to obtain the unbiased effect of each of the five decision factors.

The results showed that attitudinal decision factors (that is, career success, social fit, and individual fit) had significant influence on the student's decision to self-select into a male-dominated, female-dominated, or gender-neutral major. A closer look showed that the coefficient for career success was positive (.152) and associated with a significant $p$ value (.003), indicating that the more a student considered career success to be an important decision factor, the more likely he or she was to choose a male-dominated business major. In contrast, the coefficients for social fit and individual fit were both negative (-.163 and -.127, respectively) and associated with significant $p$ values (.003 and .011, respectively), implying that the more a student attached importance to the social and individual fit between the major choice and him or herself, the more likely he or she was to choose to major in a female-dominated field. This set of results provided strong support to the first hypothesis, which predicts that major choices are influenced by beliefs, evaluation, and attitudes, all of which are manifested by the three decision factors of career success, social fit, and individual fit.

Table 6

ANOVA Results on the Impact of Decision Factors on Business Major Choices

\begin{tabular}{lcrrrl}
\hline & Source & $S S$ & $d f$ & $M S$ & $F$ (p value) \\
\hline 1. Career success & Between groups & 7.58 & 2 & 3.79 & 6.85 \\
& Within groups & 190.27 & 347 & 0.55 & $(.0012)$ \\
2. Social fit & Between groups & 8.26 & 2 & 4.13 & 7.93 \\
& Within groups & 179.66 & 347 & 0.52 & $(.0004)$ \\
3. Individual fit & Between groups & 7.86 & 2 & 3.93 & 6.67 \\
& Within groups & 202.15 & 347 & 0.59 & $(.0014)$ \\
4. Advice & Between groups & 0.91 & 2 & 0.45 & 0.90 \\
& Within groups & 175.46 & 347 & 0.51 & $(.409)$ \\
5. Academic experience & Between groups & 1.38 & 2 & 0.69 & 1.37 \\
& Within groups & 173.97 & 347 & 0.50 & $(.255)$ \\
\hline
\end{tabular}


Table 7

Regression Analysis of the Impact of Decision Factors on Business Major Choice

\begin{tabular}{lccccccc}
\hline & \multicolumn{2}{c}{$\begin{array}{c}\text { Unstandardized } \\
\text { Coefficients }\end{array}$} & & \multicolumn{3}{c}{$\begin{array}{c}\text { Standardized } \\
\text { Coefficients }\end{array}$} \\
\cline { 2 - 5 } \cline { 5 - 7 } $\begin{array}{l}\text { Dependent Variable: } \\
\text { Gendered Major Choices }\end{array}$ & \multicolumn{1}{c}{$\mathrm{B}$} & $S E$ & & Beta & $t$ & $p$ value \\
\hline (Constant) & .744 & .247 & & & 3.008 & .003 \\
Career success & .152 & .051 & & .177 & 2.954 & .003 \\
Social fit & -.163 & .054 & & -.187 & -3.024 & .003 \\
Individual fit & -.127 & .050 & & -.154 & -2.553 & .011 \\
Advice & .022 & .052 & & .023 & .420 & .675 \\
Academic experience & .029 & .055 & & .032 & .532 & .595 \\
\hline
\end{tabular}

However, subjective norm decision factors (that is, advice from significant others and academic experience) did not have a significant impact on the choice of major. Given the interesting finding of differential effects on the decision factors on major choices reported above, an analysis was conducted to determine whether and to what extent gender might influence the three decision factors that had a significant impact on major choices. Regression analysis, as reported in Table 8, demonstrated that gender did have an impact on career success, individual fit, and advice considerations, but not on social fit or academic experience considerations. Thus, for our second hypothesis (which predicts that genderbased beliefs, evaluation, and attitudes will mediate the relationship between gender and the selection of business major) our analysis focused on the three subjective norm decision factors.

Table 8

The Impact of Gender on Decision Factors

\begin{tabular}{lccc}
\hline Dependent Variables & Independent Variables & Coefficient & $\operatorname{Pr}>|\mathrm{t}|$ \\
\hline Career success & Constant & 3.560 & .000 \\
Social fit & Gender & 0.146 & .072 \\
& Constant & 3.100 & .000 \\
Individual fit & Gender & -0.061 & .439 \\
& Constant & 4.205 & .000 \\
Advice & Gender & -0.156 & .062 \\
& Constant & 1.944 & .000 \\
Academic experience & Gender & 0.175 & .022 \\
& Constant & 3.397 & .000 \\
& Gender & -0.006 & .936 \\
\hline
\end{tabular}


Mediation and moderation analyses. Having established these observations, we conducted an analysis to explore the possible mediator role of such decision factors through a systematic test of these variables as mediators between gender and major choice. Following Baron \& Kenny (1986), to demonstrate mediation one must first establish that gender predicts significantly for the mediators of decision factors, as well as for the dependent variables of the major choice. In separate analysis, decision factors as mediators must be related to the choice of major. Finally, when the independent variables and mediators are simultaneously entered into a regression, the effects of the independent variables must drop to insignificance, whereas the mediators must maintain significant relationships.

Given that (a) gender predicts for the attitudinal decision factors of career success, social fit, and individual fit, (b) gender predicts for major choice, and (c) career success and individual fit predicts for major choice, the last step of the Baron and Kenny (1986) mediation procedure was undertaken by simultaneously regressing major choice onto gender, career success, and individual fit. The results, summarized in Table 9, showed that, when both mediators and the independent variable were utilized in the regression for major choice, the coefficients for career success and individual fit were significant (respectively, $\beta=0.104, p=.021$, and $\beta=-0.151, p=.001$ ), whereas the coefficient for gender remained significant $(\beta=0.285, p=.000)$. This pattern suggested that the effect of gender is not mediated by decision factors of career success and individual fit. Rather, all three variables have significant impact on the dependent variable, above and beyond each other's impact alone. Thus, the results provided strong support for our first hypothesis in the sense that decision factors of career success, social fit, and individual fit have significant impact on one's choice of major. However, the effect of gender is not mediated by these decision factors, failing to provide support for our second hypothesis.

Given that our hypothesized mediation framework was not supported by the data, the next step was to explore the possibility of a moderation framework. It is conceivable that men and women place differing levels of importance on various decision factors when choosing a major. To explore such a possibility, interaction terms between gender and the three decision factors were added using a moderation analysis.

Two important results emerged (see Table 10). First, with respect to the main effects, all three decision factors were significant, whereas gender is no longer significant. Second, two of the three interaction terms between gender and the decision factors were significant. The implications of this set of moderation tests are that while all students attach significant importance to career success, social fit, and individual fit when considering a major, there are differences in weighing these factors. For example, in gender-equal majors, men and women did not differ in the relative weight they give to the factors. However, when choosing a major, men were significantly more concerned than women about career success issues and significantly less concerned about the individual fit between the major and their own skills and preferences. In other words, when choosing a major, men were more likely to be influenced by which major they perceived as leading to a successful career (that is, material success/desirable career), whereas women focused more on the fit between the major and their skills, interests, and preferences. The results of this set of moderation analysis were noteworthy because they corroborated our first hypothesis by showing the precise mechanism that linked gender and decision factors to the resultant major choices. 
Table 9

Mediation Analysis

\begin{tabular}{|c|c|c|c|c|c|}
\hline \multirow{2}{*}{$\begin{array}{l}\text { Dependent Variable: } \\
\text { Choice of Major }\end{array}$} & \multicolumn{2}{|c|}{ Unstandardized Coefficients } & \multicolumn{3}{|c|}{ Standardized Coefficients } \\
\hline & $\mathrm{B}$ & $S E$ & Beta & $t$ & Sig. \\
\hline (Constant) & .496 & .228 & & 2.173 & .031 \\
\hline Gender & .285 & .068 & .217 & 4.168 & .000 \\
\hline Career success & .104 & .046 & .120 & 2.283 & .023 \\
\hline Individual fit & -.151 & .044 & -.180 & -3.424 & .001 \\
\hline
\end{tabular}

Table 10

Moderation Analysis

\begin{tabular}{lcccrc}
\hline & \multicolumn{2}{c}{ Unstandardized Coefficients } & \multicolumn{3}{c}{ Standardized Coefficients } \\
\cline { 2 - 6 } & $\mathrm{B}$ & $S E$ & Beta & \multicolumn{1}{c}{$t$} & Sig. \\
\hline (Constant) & .713 & .320 & & 2.225 & .027 \\
Gender & .138 & .446 & .106 & .309 & .758 \\
Career success & .298 & .069 & .346 & 4.315 & .000 \\
Social fit & -.192 & .078 & -.219 & -2.458 & .014 \\
Individual fit & -.222 & .066 & -.268 & -3.365 & .001 \\
Gender X career success & -.304 & .097 & -.900 & -3.142 & .002 \\
Gender X social fit & .131 & .104 & .324 & 1.267 & .206 \\
Gender X individual fit & .200 & .090 & .645 & 2.220 & .027 \\
\hline
\end{tabular}

Perceptions of the role of gender in career success. In the survey, students were also asked to assess the likelihood of men and women being successful in each of the career fields matched to major programs. As with the major choices students made, there were important gender differences in their subjective assessment of the likelihood of career success for men and women in various business disciplines. Such subjective assessments painted a picture parallel to the gender segregation into various business disciplines.

Table 11 shows that both women and men viewed men as having a significantly greater chance of success than women in all specializations (careers) as indicated by the $t$ test of difference in means of men and women and their significant $p$ values, except in the female-dominated field of human resources management, where women are seen as more likely to succeed, and in marketing, where there is little difference. In other words, all respondents believed men were more likely to succeed across most of the specializations, and in almost all cases women predicted more of a gendered success gap than did men. Women who opted for the human resources major, the only female-dominated specializa- 
tion, predicted a greater male advantage outside their own area (HRM) than did women in either male-dominated or gender-neutral fields. The advantage they perceive in such male-dominated fields as finance and management, for example, is about .3 higher (that is, the difference in means on a 5 -point scale) than the advantage perceived by women in the predominantly male majors. This difference was not large, but it may have reflected some adjustment of their views to support their choice of human resources as a major.

Table 11

Perception/Assessment of Women's/Men's Success in Career Fields by Gender

\begin{tabular}{|c|c|c|c|c|c|c|}
\hline $\begin{array}{l}\text { Assessment of } \\
\text { Chance of } \\
\text { Success }^{\text {a }}\end{array}$ & $\begin{array}{c}\text { Women's } \\
\text { Assessment } \\
\text { of Other } \\
\text { Women }\end{array}$ & $\begin{array}{c}\text { Women's } \\
\text { Assessment } \\
\text { of Men }\end{array}$ & $\begin{array}{c}\text { Men's } \\
\text { Assessment } \\
\text { of Women }\end{array}$ & $\begin{array}{c}\text { Men's } \\
\text { Assessment } \\
\text { of Other } \\
\text { Men }\end{array}$ & $\begin{array}{l}\text { Gap in Total } \\
\text { Assessment } \\
\text { of Women } \\
\text { and Men }\end{array}$ & $\begin{array}{c}t \text { test } \\
\text { (two- } \\
\text { tailed } \\
p \text { values) }\end{array}$ \\
\hline Accounting & 4.0 & $4 \cdot 4$ & 3.8 & $4 \cdot 3$ & .41 & $\begin{array}{l}7.58 \\
(.000)\end{array}$ \\
\hline $\begin{array}{l}\text { Economics } \\
\text { and Manage- } \\
\text { ment Science }\end{array}$ & $3 \cdot 5$ & $4 \cdot 4$ & 3.4 & 4.1 & .78 & $\begin{array}{l}13.81 \\
(.000)\end{array}$ \\
\hline $\begin{array}{l}\text { Entrepre- } \\
\text { neurship }\end{array}$ & $3 \cdot 3$ & $4 \cdot 4$ & 3.2 & 4.2 & 1.01 & $\begin{array}{l}16.32 \\
(.000)\end{array}$ \\
\hline Finance & 3.7 & $4 \cdot 4$ & 3.5 & 4.2 & .70 & $\begin{array}{l}12.36 \\
(.000)\end{array}$ \\
\hline $\begin{array}{l}\text { Human } \\
\text { Resources } \\
\text { Management }\end{array}$ & 4.4 & $3 \cdot 4$ & $4 \cdot 3$ & 3.2 & -1.00 & $\begin{array}{r}-13.18 \\
\text { (.000) }\end{array}$ \\
\hline $\begin{array}{l}\text { General } \\
\text { Management }\end{array}$ & 3.4 & $4 \cdot 4$ & $3 \cdot 4$ & $4 \cdot 3$ & .96 & $\begin{array}{l}14.21 \\
(.000)\end{array}$ \\
\hline Marketing & $3 \cdot 9$ & 4.1 & 4.0 & $3 \cdot 9$ & .02 & $\begin{array}{l}0.34 \\
(.737)\end{array}$ \\
\hline
\end{tabular}

${ }^{a}$ Assessment of women's and men's chances on a 5-point scale, where 5 is very successful.

${ }^{\mathrm{b}}$ Assessment by women and men combined and averaged.

\section{Conclusion}

This study found that students employ the same factors when making decisions about which business specialization to pursue. To all students, perceptions about individual fit, career success, and prior academic experience mattered most. Perceptions about social fit and advice from referent others turned out to be less important. In other words, men and women use the same criteria, and with the same ordering of factors, in selecting a major. Our in-depth analysis, however, revealed that even though all students emphasize the same factors when making specialization choices, they attach different weight to these factors in a pattern that is gendered. In particular, the more weight a student gives career success as a decision factor, the more likely he or she is to choose a male-dominat- 
ed business major, whereas the more weight a student gives fit as a decision factor, the more likely he or she is to choose a female-dominated major. In other words, males are significantly more concerned with career success issues and significantly less concerned about individual fit and social fit. What this finding means is that men are more likely to be drawn to a major they imagine will lead to material success, social status, and prestige, and they perceive these majors to be Entrepreneurship, Finance, and Economics and Management Science. Women are more likely to seek a major they believe will be a good fit with their skills, interests, and preferences, and they perceive this major to be Human Resources Management. Interestingly, in the two gender-neutral majors-Accounting and Marketing-men and women weigh the factors equally.

Our study also suggested that that both women and men view men as having a significantly greater chance of success in all specializations (and ultimately careers) than do women, except for the female-dominated field of human resources management. The area in which women are seen as equally likely to succeed is marketing. In other words, all respondents believe men are more likely to succeed across most of the specializations, and in almost all cases women predict more of a gendered success gap than do men. Women who opt for the human resources major, the only female-dominated specialization, predict a greater male advantage outside their own area than do women in either male-dominated or gender-neutral fields.

These findings have important implications for educators and society at large. By better understanding the underlying reasons for students' specialization choice, educators can design appropriate intervention programs and strategies to correct misunderstandings and biases and possibly influence outcomes. Because men tend to weigh career success as a very important factor when selecting a business major, strategies could be developed to highlight career and material success possibilities in the human resources management field. Alternatively, because women value fit as a factor when making major choice, strategies can be developed to highlight the potential for a good fit and intrinsic goal achievement in fields such as finance and entrepreneurship. As a result, input into attitudinal factors have the potential to moderate the relationship between gender and career choice.

The study suggested that the influence of subjective norms (advice from others and academic experience) is less significant in influencing choices for both men and women. In light of this finding, educators might consider orientating students to the potential for extrinsic and intrinsic goal achievement across management specialties. For example, the need for finance graduates in the volunteer and non-profit sectors might be one way to illustrate the requirement for these skills in a broad group of organizational settings, including settings where more altruistic values dominate. Similarly, the strategic role played by these professionals could be highlighted, emphasizing that human resources professionals are part of the senior executive team in many companies and are rewarded accordingly. Featuring role models that embody gender diversity in various business disciplines might help students remain open to the multitude of opportunities for material and humanistic goal achievement across business disciplines.

Our study considered specialization choice in a large sample of students from a Canadian university, but there is no reason to expect significant differences in findings in other settings with similar cultural frameworks. Students in this sample had already chosen their major, and they were asked to reflect on a set of factors they might have used 
when making these decisions. Thus, our correlation survey design has some methodological limitations. Only single-source (self-report), one-sectional (retrospective) correlation data were employed for the analyses. Hence, it is conceivable that self-serving attribution biases and imperfect recall may compromise the accuracy of individuals' retrospective accounts and perceptions of their experiences. However, these idiosyncratic perceptions are exactly the phenomenon we were interested in.

In addition, this study used a set of five key factors identified in the literature as influencing specialization choice. Nonetheless, other factors that we did not measure might also be playing a role in how students make decisions. Factors such as the reputation of the school, the types of firms that come to recruit on campus, the real and perceived job market in each specialization, and demographic factors other than gender (for example, race and ethnicity). Thus, future studies could attempt to collect information from students before they had made their choice to see if they reported using the same decision factors when contemplating a choice of major. A more rigorous test of the concepts discussed in this paper would require a longitudinal study with data collection of independent and dependent variables obtained sequentially. Future research might also employ cross-sectional, multiple-source design to enhance the causality argument. Lastly, because our study used a survey method, it would be instructive if others were to interview students or set up focus groups to probe further, especially to delve into other factors that might be influencing student choice.

A lasting value of our current research is that it offers one of the first attempts to understand specialization choice in a business education environment, through a gendered lens. The findings are of value to educators concerned about the impact of sex segregation in business education programs and careers, and for educators and policy-makers committed to helping students make informed decisions about career choices.

\section{Note}

1 The major called Management is mostly concerned with quantitative aspects of business management, such as project management, production and operations management, statistics, the management of logistics, and management control systems.

\section{References}

Aaker, J. (2000). Accessibility or diagnosticity? Disentangling the influence of culture on persuasion processes and attitudes. Journal of Consumer Research, 26(March), 340357 .

Ajzen, I., \& Fishbein, M. (1980). Understanding and predicting social behavior. Englewood, NJ: Prentice Hall.

Alloway, N., \& Gilbert, P. (2004). Shifting discourses about gender in higher education enrolments: Retrieving marginalized voices. International Journal of Qualitative Studies in Education, 17(1), 99-112.

Aveling, N. (2002). Having it all and the discourse of equal opportunity: Reflections on choices and changing perceptions. Gender and Education, 14(3), 265-280. 
Baron, R., \& Kenny, D. (1986). The moderator-mediator variable distinction in social psychological research: Conceptual, strategic, and statistical consideration. Journal of Personality and Social Psychology, 51(6), 1173-1182.

Bowbly, J., \& McMullen, K. (2002). At a crossroads-First results for the 18 to 20-year-old cohort of the youth in transition survey (Catalogue No. 81-591-X). Ottawa, ON: Statistics Canada.

Canadian Association of University Teachers (CAUT). (2002). Almanac of postsecondary education in Canada (2002 edition). Ottawa, ON: Author.

Canadian Association of University Teachers (CAUT). (2009). Almanac of postsecondary education in Canada (2009 edition). Ottawa, ON: Author.

David, M., Ball, S., Davies, S., \& Reay, D. (2003). Gender issues and parental involvement in student choices of higher education. Gender and Education, 15(1), 21-37.

Dryler, H. (1998). Parental role models and education choice. British Journal of Sociology, 49(3), 375-398.

Erwin, L., \& Maurutto, P. (1998). Beyond access: Considering gender deficits in science education. Gender and Education, 10(1), 51-69.

Ferreira, M. (2003). Gender issues related to graduate student attrition in two science departments. International Journal of Science Education, 25(8), 969-989.

Finnie, R., Laporte, C., \& Lascelles, E. (2004). Family background and access to post-secondary education: What happened over the 1990's? (Catalogue No. 11Fo019MIE2004226). Ottawa, ON: Statistics Canada.

Fishbein, M., \& Ajzen, I. (1975). Belief, attitude intention and behavior: An introduction to theory and practice. Reading, MA: Addison-Wesley.

Franke, S. (2004). School, work and the school-work combination by young people (Catalogue No. 89-584-MIE2003003). Ottawa, ON: Statistics Canada.

Gough, B., \& Peace, P. (2000). Reconstructing gender at university: Men as victims. Gender and Education, 12(3), 385-398.

Greenfield, S., Parle J., \& Holder, R. (2001). The anxieties of male and female medical students on commencing clinical studies: The role of gender. Education for Health, 14(1), $61-73$.

Harris, P., Thiele, B., \& Currie, J. (1998). Success, gender and academic voices: Consuming passion or selling the soul. Gender and Education, 1O(2), 133-148.

Hatchell, H. (1998). Girls' entry into higher secondary sciences. Gender and Education, $10(4), 375-386$.

Hébert, T. (2000). Gifted males pursuing careers in elementary education: Factors that influence a belief in self. Journal for the Education of the Gifted, 24(1), 7-45.

Herzig, A. (2004). Becoming mathematicians: Women and students of color choosing and leaving doctoral mathematics. Review of Educational Research, 74(2), 171-214.

Le, A., \& Miller, P. (2002). The rising education levels of females in Australia. Education Economics, 1O(1), 1-24. 
Loo, R. (2002). The distribution of learning styles and types for hard and soft business majors. Educational Psychology, 22(3), 349-360.

Marks, A. (2003). Welcome to the new ambivalence: Reflections on the historical and current cultural antagonism between the working class male and higher education. British Journal of Sociology of Education, 24(1), 83-93.

Mastekaasa, A., \& Smeby, J. (2008). Education choice and persistence in male- and female-dominated fields. Higher Education, 55, 189-202.

Moogan, Y., \& Baron, S. (2003). An analysis of student characteristics within the student decision making process. Journal of Further and Higher Education, 27(3), 271-287.

Noguera, P. (2003). The trouble with black boys: The role and influence of environmental and cultural factors on the academic performance of African American males. Urban Education, 38(4), 431-459.

O’Brien, M. (2003). Girls and transition to second-level schooling in Ireland: Moving on and moving out. Gender and Education, 15(3), 249-267.

Pullen, A., \& Simpson, R. (2009). Managing difference in feminized work: Men, otherness and social practice. Human Relations, 62(4), 561-587

Rask, K., \& Bailey, E. (2002). Are faculty role models? Evidence from major choice in an undergraduate institution. Research in Economic Education, 33(2), 99-124.

Statistics Canada. (2009). Full-time university enrolment, by sex, and by province, selected years, 1920-1975. Retrieved from http://www.statcan.gc.ca/pub/11-516-x/ sectionw/4147445-eng.htm\#3

Stone, L., \& McKee, N. (2000). Gendered futures: Student visions of career and family on a college campus. Anthropology and Education Quarterly, 31(1), 67-89.

Tilleczek, K., \& Lewko, J. (2001). Factors influencing the pursuit of health and science careers for Canadian adolescents in transition from school to work. Journal of Youth Studies, 4(4), 415-428.

Tinklin, T. (2003). Gender differences and high attainment. British Educational Research Journal, 29(3), 307-325.

Trusty, J. (2002). Effects of high school course-taking and other variables on choice of science and mathematics college majors. Journal of Counseling and Development, 8o(4), 464-474.

Warrington, M., \& Younger, M. (2000). The other side of the gender gap. Gender and Education, 12(4), 493-508.

\section{Acknowledgements}

This research was conducted with financial assistance from the Office of Research at Ryerson University. We wish to thank the three anonymous authors for a number of very helpful and useful suggestions that were incorporated into this manuscript. 


\section{Contact Information}

Gerald Hunt

Ted Rogers School of Management

Ryerson University

350 Victoria Street

Toronto, ON M5B $2 \mathrm{~K}_{3}$ Canada

ghunt@ryerson.ca

Gerald Hunt is a Professor at the Ted Rogers School of Management, Ryerson University, Canada. His research interests focus on organizational change, as well as gender and diversity in the workplace. Many of his publications have dealt with labour union response to diversity issues.

Fei Song is an Associate Professor at the Ted Rogers School of Management, Ryerson University, Canada. She received her PhD in Organizational Behaviour/Industrial Relations from the Schulich School of Business, York University. Her research interests include behavioural decision-making, cross-cultural issues, and strategic compensation. She has published in the Academy of Management Journal, Organizational Behavior and $\mathrm{Hu}$ man Decision Processes, Management and Organization Review, Games and Economic Behavior, International Journal of Conflict Management, Experimental Economics, and Journal of Economic Psychology. 